\title{
Demand and proximity: drivers of illegal forest resource extraction
}

\author{
Catrina A. Mackenzie and Joel Hartter
}

\begin{abstract}
Illegal extraction from protected areas is often shaped by the surrounding socio-economic landscape. We coupled village-scale socio-economic parameters collected using household surveys with measured levels of illegal resource extraction proximate to study villages to investigate the socio-economic drivers of illegal extraction from Kibale National Park, Uganda. The level of illegal tree harvesting and the number of illegal entry trails into the Park were driven by subsistence demand from villages adjacent to the Park and by for-profit extraction to supply local urban markets, whereas grazing in the Park was linked to high livestock ownership. Capital asset wealth, excluding livestock, was found to mitigate illegal resource extraction from the Park. We also found high human population density to coincide spatially with park-based tourism, research and carbon sequestration employment opportunities. Conservation strategies should be integrated with national policy to meet the needs of local communities and to manage urban demand to reduce illegal extraction from protected areas.
\end{abstract}

Keywords Degradation, fuelwood, Kibale National Park, population density, protected area, tropical forest, Uganda

\section{Introduction}

ach year the world loses an estimated $13 \mathrm{~m}$ ha of forest

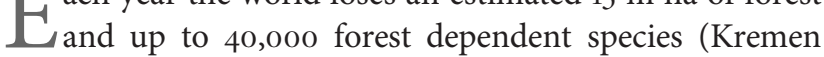
et al., 2000). Many threatened forests are located in regions of poverty (Sunderlin et al., 2005). Households often need resources available in protected areas, such as wood for cooking, heating and construction (Naughton-Treves et al., 2007), grasslands for livestock grazing (Infield et al., 1993; Neumann, 1998; Kideghesho et al., 2007) and wild animals for meat (Neumann, 1998; Chapman et al., 2006). Thus, subsistence-based livelihoods are often perceived as a threat to conservation (Mbile et al., 2005).

Land conversion for agriculture and demand for wood has driven deforestation across Africa (Tole, 1998; Dovie et al., 2004), with increasing human population density

CAtrina A. MACKenZIE (Corresponding author), Department of Geography, McGill University, 805 Rue Sherbrooke Ouest, Montreal, Quebec H3A 2K6, Canada. E-mail catrina.mackenzie@mail.mcgill.ca

JoEl HartTER Department of Geography, New Hampshire University, Durham, New Hampshire, USA

Received 13 September 2011. Revision requested 10 December 2011.

Accepted 11 January 2012 further accelerating deforestation rates (Cropper \& Griffiths, 1994; Tole, 1998). Forests are also under pressure from demand from urban centres for charcoal and fuelwood (McDonald et al., 2009; Ahrends et al., 2010). Conservationists cite increased demand for natural resources spurred by growing human populations as the greatest threat to protected areas (Brook \& Bradshaw, 2006) and African tropical montane forests (Rondinini et al., 2006; Burgess et al., 2007). The pressure may be further magnified by migration of people to protected area boundaries, either in search of land (Mwamfupe, 1998) or employment (Newmark \& Hough, 2000; Wittemyer et al., 2008).

Forest resource dependency has been linked to household wealth and education, suggesting illegal extraction from protected areas could be mitigated by development (Adams et al., 2004). Increased wealth can result in more positive attitudes towards protected areas (Infield, 1988; Gillingham \& Lee, 1999) but also an increased desire to extract protected area resources for profit (Holmes, 2003; Fisher \& Shively, 2005). Lack of education is correlated with negative attitudes toward conservation and a desire to de-gazette parks in South Africa (Infield, 1988), whereas in Tanzania the perceived benefit of wildlife increased with higher levels of education (Gillingham \& Lee, 1999).

In Africa attitudes towards protected areas are often shaped by the socio-economic landscape (Masozera \& Alavalapati, 2004; Kideghesho et al., 2007). Less clear is whether attitudes translate into behaviours (Holmes, 2003). A pragmatic indicator of support for conservation is whether communities extract resources illegally from a protected area (Bruner et al., 2001). Self-reporting of resource extraction from protected areas is prone to bias, as people tend to underreport or are unwilling to admit to illegal behaviour (St John et al., 2010). Measured illegal extraction cannot be attributed to any one household but does provide an objective assessment of resource poaching. Therefore, to assess whether socio-economic factors influence illegal resource extraction we have aggregated survey data from villages adjacent to Kibale National Park, a mid altitude forest park in Uganda, for comparison with measured extraction within the boundary of the Park. Acknowledging that aggregating data masks individual motivations to enter the Park, we use village-scale socio-economic factors found to statistically influence illegal resource extraction as the basis for our policy recommendations to improve conservation of tropical forest protected areas. 


\section{Study site}

In Uganda human population density is increasing by $3.2 \%$ per annum (Uganda Bureau of Statistics, 2009), and $>80,000$ ha of tree cover are lost per year (Uganda Ministry of Water and Environment, 2011), making protection of forest habitats for biodiversity critical. Kibale National Park is a $795 \mathrm{~km}^{2}$ forest and savannah protected area in western Uganda (Fig. 1), located within $15 \mathrm{~km}$ of the urban centre of Fort Portal. Conservation policy is exclusion and enforcement of park boundaries by the Uganda Wildlife Authority, tempered by resource access agreements and tourism revenue sharing (Uganda Wildlife Statute, 1996). The Park is home to the largest population of chimpanzees Pan troglodytes schweinfurthii in East Africa (Plumptre et al., 2003) and attracts $>7,000$ tourists per year (Uganda Wildlife Authority, 2009), providing tourism-related employment for $>250$ people, $87 \%$ from local villages. The Park also attracts researchers to the Makerere Biological Field Station to study primates (Chapman \& Lambert, 2000), aquatic systems (Chapman et al., 2004), forest ecology (Omeja et al., 2009) and conservation management (Lepp \& Holland, 2006; Hartter \& Goldman, 2011). As of January 2010 research activities employed 93 people, $91 \%$ of these from local villages. A carbon sequestration partnership has been established between the Uganda Wildlife Authority and FACE the Future Foundation (FACE) employing, in 2008, $>300$ people to plant indigenous trees.

Most local inhabitants are subsistence farmers affiliated with the Batooro tribe (north) or the Bakiga tribe (south). All cooking, heating, alcohol and brick production is fuelled by wood (Naughton-Treves et al., 2007). Rural households also depend on the Park for craft materials, medicinal plants and bark, and as a place to put beehives (Hartter, 2010).

People live in villages of $\mathrm{c} .100$ households governed by a village council led by a village chairperson. We define a village as the spatial extent of households associated with a village name under the leadership of one village chairperson. Study villages were located c. $5 \mathrm{~km}$ apart and were chosen based on village members holding and/or cultivating land directly adjacent to the Park. Twenty-five villages, representing c. $40 \%$ of park-bordering villages within our boundary measurement zone (Fig. 1), participated in our survey during May-August 2008 and 2009. Study households were located 15-3,300 m from the Park boundary. Eleven villages had residents who were employed by researchers, tourism facilities, or FACE.

\section{Methods}

\section{Data collection}

Data on population, education, wealth assets, and incomegenerating activity were collected using a household survey. In each village we recorded all household locations using a global positioning system (GPS), and noted the number of buildings per household compound and the construction standard of each primary dwelling. Villages contained 41-242 households (median $=84$ ).

Twenty-four households (10-59\% of village households) were surveyed in each village and wealth stratified by primary dwelling construction, where mud and wattle indicated a poorer household, and brick a richer household
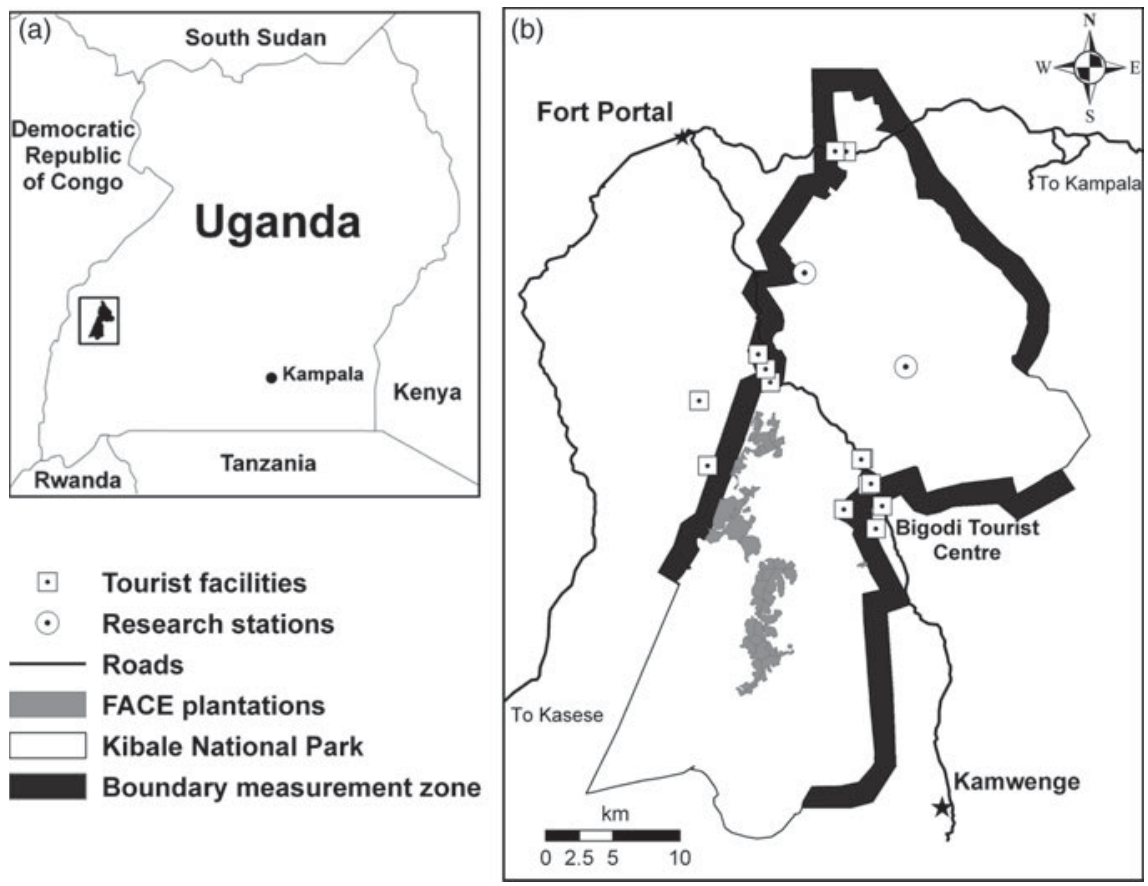

FIG. 1 (a) Location of Kibale National Park (rectangle) in Uganda, and (b) the Park, showing the location of tourist facilities, research stations, FACE the Future Foundation (FACE) plantations, and those sections of the Park boundary where measurements were made (see text for details). 
(Ellis \& Bahiigwa, 2003; Hartter, 2009). Wealth stratification was used to ensure inclusion of poorer households that are less likely to be represented by random sampling (Takasaki et al., 2000) and may be more dependent on natural resources. Four Ugandan field assistants, using the two local languages, surveyed a total of 596 households (wealth: $33.4 \%$ low, $51.3 \%$ medium, $15.3 \%$ high), representing $24 \%$ of all households. Survey participants were free not to answer any question, and rather than impute data, given household statistics report the actual number of responses.

Data included household composition, whether the household head had migrated to the village, and education attained by each household member. Village population density was calculated by multiplying the mean number of people per household in a village by the number of village households, divided by village area. Urban market access was represented by the road distance from the village to the nearest urban centre, based on a road network mapped using GPS tracks.

Wealth assets, including land holdings, livestock, radios, cell phones, bicycles and motorcycles, were recorded and valued using market prices from districts around the Park. We also recorded the income-generating activities that the household engaged in (e.g. employment, sales, cash crops). The value of buildings within a household compound, including dwellings and outbuildings, was converted to a Building Wealth Unit by dividing the value of all buildings by the value of a medium category primary dwelling. Livestock ownership was converted to a Cattle Equivalent Unit by summing the value of cows, goats, sheep, pigs and chickens owned, and dividing by the value of one cow (Ellis \& Bahiigwa, 2003), such that a Cattle Equivalent Unit could be one cow, five goats, or 40 chickens. Similarly, the summed value of radios, cell phones, bicycles, and motorcycles was divided by the value of one bicycle to create a Bicycle Equivalent Unit to represent communication and transportation devices owned by the household. Household capital asset wealth was the sum of the market value of all these assets.

Resource extraction was measured by walking a 600-850 $\mathrm{m}$ transect of the boundary between each of the 25 study villages and the Park. We recorded the number of harvested trees, entry trails, livestock inside the Park and evidence of wildlife poaching (Olupot \& Chapman, 2006). All illegal entry trails were followed to their terminus to record the same information. Uganda Wildlife Authority records of resource access agreements were used to remove legally harvested trees and sanctioned entry trails from the data. Measured extraction from each village boundary was normalized by the length of boundary sampled for that village and treated as an independent data point to be compared with village-aggregate survey data from the adjacent village.
Questions about illegal resource extraction are prone to non-response and social undesirability biases (St John et al., 2010). Although complex survey methodologies have attempted to elicit more accurate measures of illegal activity (Solomon et al., 2007) we employed a direct questioning approach, empathizing with the need for natural resources and asking if respondents ever entered the Park to collect resources. Expecting that extraction would be underreported we considered the data as potentially useful to identify trends, not absolute levels of extraction. Since the number of respondents admitting extraction of Park resources was higher closer to the Park boundary $\left(r_{\mathrm{s}}=-0.322, \mathrm{P}<0.001\right.$, $\mathrm{n}=573$ ), the number of households within $1 \mathrm{~km}$ of the Park, the typical upper bound of distance to travel for forest resources (Naughton-Treves et al., 2007), was used as a variable to capture the number of households that could be opportunistically more prone to resource extraction.

\section{Analysis}

As this study deals with illegal extraction there is the potential for retribution should study villages be explicitly identified (Robbins et al., 2006). Although village-specific data was used for all analyses, to protect village identity geographical masking was used for published results (Leitner \& Curtis, 2004) by interpolating to rasterize data on a $1,000 \mathrm{~m}$ grid and then resampling to a resolution of $30 \mathrm{~m}$ within the boundary measurement zone.

All household-scale correlations are non-parametric (Spearman, $r_{\mathrm{s}}$ ) because the data were not normally distributed. However, once aggregated to village-scale, most socio-economic variables, with the exception of sales to tourist facilities, were normally distributed, permitting parametric (Pearson, $r$ ) correlations to be used. Measured illegal extraction data was normally distributed for tree harvesting and entry trails but not for grazing in the Park and poaching signs.

Isolating and determining the relative weight of factors influencing illegal resource extraction is difficult because many non-quantifiable factors influence behaviour (e.g. local traditions, personal experiences and perceptions of intrinsic value). However, we explored the influence of quantifiable socio-economic factors on measured resource extraction using a linear regression model, including the following village-aggregate variables: population density, in-migration, years of education attained by adults, wealth (separately including land, buildings, livestock, communication and transportation devices, employment and income-generating activities), road distance to the nearest urban centre, and the number of households within $1 \mathrm{~km}$ of the Park boundary.

Regression models based on these 11 variables were built for each measure of illegal extraction: trees harvested per $\mathrm{km}$ 
of boundary, illegal entry trails per km of boundary, number of livestock grazing in the Park, and number of poaching signs found. Independent variables were systematically removed from each model using backward step-wise regression, based on variable $F$-test significance $(\mathrm{P}<0.1)$, and models were tested for spatial autocorrelation (Moran's $I, \mathrm{P}<0.05)$.

\section{Results}

\section{Socio-economic landscape}

Population density (Fig. 2a) On average, households were home to six people. The number of children $<_{1}$ year of age indicated a live birth rate of 53 per 1,000. Fifty-two percent of the population was under the age of 15 , indicating a strong potential for natural growth when coupled with the high birth rate. Village population density was $70-611$ per $\mathrm{km}^{2}$ (Table 1) and 56\% of heads of households were born outside their village. Village population densities increased closer to FACE plantations $(r=-0.465, \mathrm{P}=0.019, \mathrm{n}=25)$, as did in-migration $(r=-0.569, \mathrm{P}=0.003, \mathrm{n}=25)$, suggesting people may be moving for employment. The shortest straight-line distance from a village to either a FACE plantation, tourist facility, or research station, correlated with village population density $(r=-0.501$, $\mathrm{P}=0.011, \mathrm{n}=25$ ), with denser populations occurring closer to park-generated employment.

Education (Fig. 2b) Only $24 \%$ of adults had completed primary school. Men had completed on average 5.4 years of school whereas women had completed 3.4 years (Table 1).

Wealth (Fig. 2c) A typical household compound contained one primary and one secondary dwelling, with $0-7$ outbuildings. Ninety-four percent of survey households
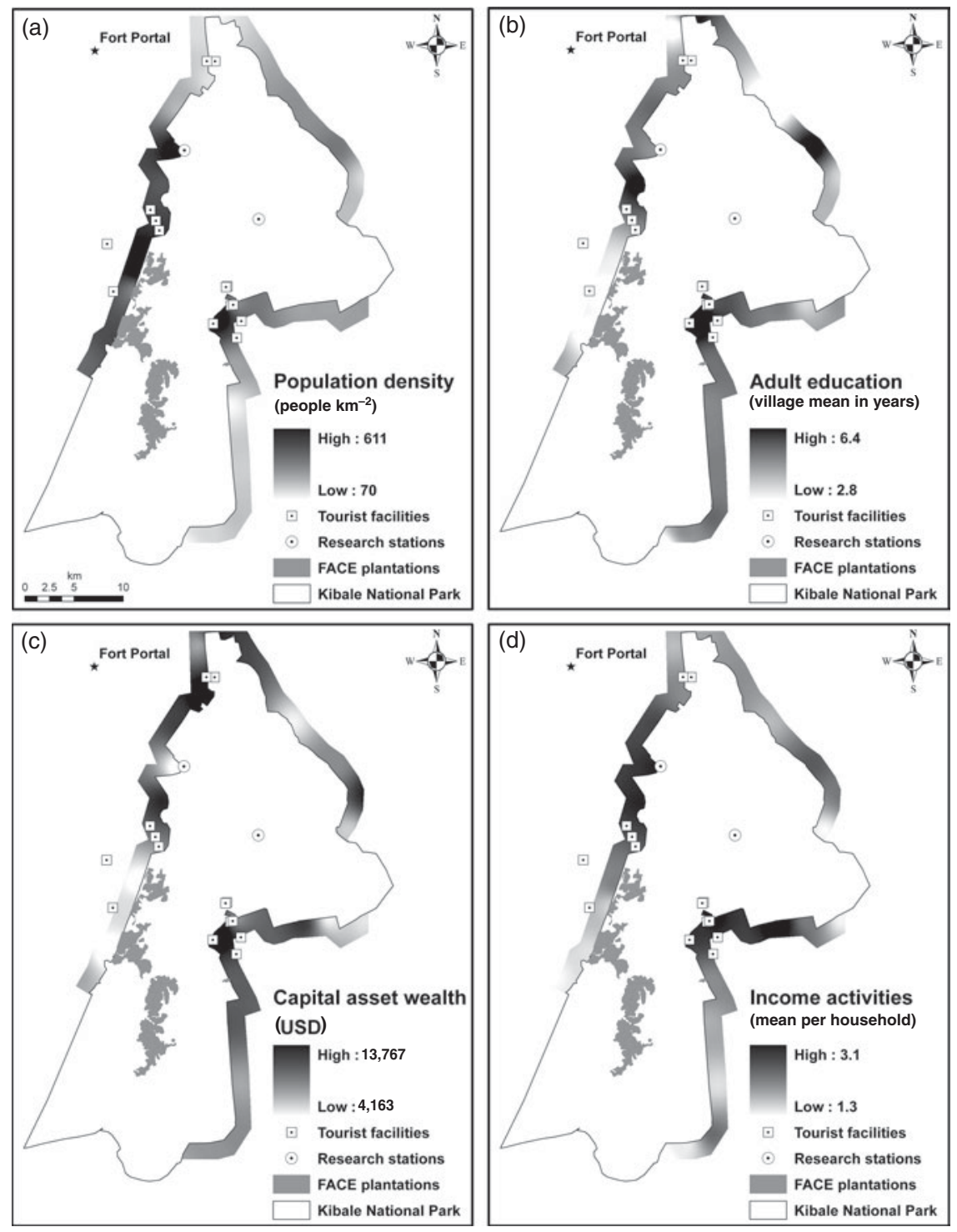

FIG. 2 Spatial distribution of socioeconomic variables around Kibale National Park (Fig. 1). 
TABLE 1 Socio-economic variables (mean, minimum and maximum) for the 25 study villages, by indicator, around Kibale National Park, Uganda (Fig. 1).

\begin{tabular}{|c|c|c|c|c|}
\hline Indicator & Variable & Mean & Min. & Max. \\
\hline \multirow[t]{3}{*}{ Population } & Population density (people $\mathrm{km}^{-2}$ ) & 241 & 70 & 611 \\
\hline & In-migration (\% household heads who moved to the Park) & 56 & 21 & 91 \\
\hline & No. of households within $1 \mathrm{~km}$ of Park boundary & 60 & 13 & 124 \\
\hline \multirow[t]{4}{*}{ Education } & Village mean years of education for all adults & 4.3 & 2.8 & 6.4 \\
\hline & Adult literacy (\% finishing primary school) ${ }^{1}$ & 24 & 7 & 48 \\
\hline & Years of education, men & 5.2 & 0 & 16 \\
\hline & Years of education, women & 3.3 & 0 & 14 \\
\hline \multirow[t]{10}{*}{ Wealth } & Village mean household capital asset wealth (USD) & 7,777 & 4,163 & 13,767 \\
\hline & Household capital asset wealth (USD) & 7,423 & 119 & 132,541 \\
\hline & Village mean building wealth unit ${ }^{2}$ & 1.9 & 0.9 & 3.2 \\
\hline & Building wealth unit per household & 1.71 & 0.04 & 11.1 \\
\hline & Village mean land owned per household (ha) & 4.1 & 1.9 & 8.3 \\
\hline & Land owned per household (ha) & 4.1 & 0 & 100 \\
\hline & Village mean cattle equivalent units per household ${ }^{3}$ & 2.1 & 0.3 & 11.8 \\
\hline & Cattle equivalent units per household & 2.1 & 0 & 213 \\
\hline & Village mean bicycle equivalent units per household ${ }^{4}$ & 1.8 & 0.7 & 4.2 \\
\hline & Bicycle equivalent units per household & 1.8 & 0 & 48 \\
\hline \multirow[t]{13}{*}{ Income activities } & Employment (\% survey adults employed) & 22 & 2 & 51 \\
\hline & Village mean no. of income activities per household & 2.1 & 1.3 & 3.1 \\
\hline & Percent of households in village & & & \\
\hline & Selling excess food crops & 84 & 54 & 100 \\
\hline & Growing cash-crops (tea, tobacco, coffee, vanilla, cocoa and Artemisia) & 41 & 8 & 91 \\
\hline & Owning wood-lots & 18 & 0 & 58 \\
\hline & Owning a retail shop & 13 & 0 & 29 \\
\hline & Producing honey & 7 & 0 & 26 \\
\hline & Selling food, fuelwood/charcoal or crafts to tourism & 4 & 0 & 31 \\
\hline & Selling firewood & 3 & 0 & 25 \\
\hline & Making charcoal & 5 & 0 & 42 \\
\hline & Making bricks & 3 & 0 & 13 \\
\hline & Making alcohol & 4 & 0 & 22 \\
\hline Market access & Road distance to Fort Portal (km) & 41.78 & 14.42 & 77.10 \\
\hline
\end{tabular}

${ }^{1}$ For persons 15 years and older

${ }^{2}$ Value of all buildings in household compound divided by the value of a medium category primary dwelling

${ }^{3}$ Value of all livestock in a household divided by the market value of one cow

${ }^{4}$ Summed value of radios, cell phones, bicycles and motorcycles divided by the market value of one bicycle

claimed ownership (customary and freehold) of land and $26 \%$ owned land in the village and elsewhere. The average household owned 4.1 ha (median $=2$ ha), with $6 \%$ owning $>10$ ha, and $34 \%<2$ ha. To increase land for cultivation $39 \%$ of households rented or borrowed additional land. Larger households tended to own more land $\left(r_{\mathrm{s}}=0.284\right.$, $\mathrm{P}<0.001, \mathrm{n}=561$ ), as did more educated households $\left(r_{\mathrm{s}}=0.217, \mathrm{P}<0.001, \mathrm{n}=561\right)$. Chickens were the most commonly owned livestock ( $82 \%)$, followed by goats $(64 \%)$, pigs $(46 \%)$, cows $(20 \%)$ and sheep (11\%). Households owning more land tended to own more livestock $\left(r_{\mathrm{s}}=0.461\right.$, $\mathrm{P}<0.001, \mathrm{n}=567)$. Most households $(83 \%)$ owned a radio and $39 \%$ had cell phones, even though none had electricity. For transportation, $53 \%$ of households owned a bicycle but only $8 \%$ owned a motorcycle. Larger $\left(r_{\mathrm{s}}=0.256\right.$, $\mathrm{P}<0.001, \mathrm{n}=586)$ and more educated $\left(r_{\mathrm{s}}=0.308\right.$, $\mathrm{P}<0.001, \mathrm{n}=580$ ) households owned more motorcycles, bicycles, radios and cell phones. The mean capital asset wealth was USD 7,423 (median $=$ USD 5,033), range USD 119-132,541, indicating considerable wealth stratification within communities. Land holdings (58\%) and buildings (33\%) contributed most to capital asset wealth, compared to livestock (8\%) and communication/transportation devices $(2 \%)$.

Income-generating activities (Fig. 2d) Income was generated through off-farm employment (30\% of households), selling excess food production (84\%), growing cash crops (40\%), owning wood-lots (18\%), owning a retail shop (13\%), making honey (7\%), selling food, fuel or crafts to tourists (4\%) and by selling firewood, charcoal, bricks or home-brewed alcohol $(12 \%)$. Larger $\left(r_{\mathrm{s}}=0.330, \mathrm{P}<0.001, \mathrm{n}=580\right)$ and more educated $\left(r_{\mathrm{s}}=0.294, \mathrm{P}<0.001, \mathrm{n}=575\right)$ households were engaged in more income-generating activities. The 
TABLE 2 Illegal resource extraction from the boundaries of Kibale National Park, Uganda (Fig. 1).

\begin{tabular}{lcccc}
\hline Recorded variable & $\begin{array}{l}\text { Mean per } \\
\text { village } \pm \text { SD }\end{array}$ & $\begin{array}{l}\text { Total } \\
\text { recorded }\end{array}$ & $\begin{array}{l}\text { Per km of } \\
\text { boundary }\end{array}$ & $\begin{array}{l}\text { No. of villages } \\
\text { involved }\end{array}$ \\
\hline No. of harvested trees & $112 \pm 99$ & 2,794 & 143.6 & 25 \\
No. of entry trails & $2.8 \pm 3.7$ & 73 & 3.8 & 15 \\
No. of livestock grazing in Park & $13.8 \pm 41.9$ & 373 & 19.0 & 9 \\
No. of poaching signs found & $0.89 \pm 2.8$ & 24 & 1.2 & 6 \\
\hline
\end{tabular}

TABLE 3 Linear regression analysis using socio-economic variables to model illegal resource extraction.

\begin{tabular}{|c|c|c|c|}
\hline Resource & Model variable & Standardized $\beta$ & Model statistics \\
\hline \multirow{4}{*}{$\begin{array}{l}\text { Harvested trees per } \mathrm{km} \\
\text { of boundary }\end{array}$} & Road distance to Fort Portal & -0.434 & \multirow{4}{*}{$\begin{array}{l}\text { Adjusted } R^{2}=0.553, F=8.423, \mathrm{P}<0.001 \\
\text { Moran's } I=0.129, \mathrm{P}=0.235\end{array}$} \\
\hline & $\begin{array}{l}\text { Transport/communication devices } \\
\text { (bicycle equivalent units) }\end{array}$ & -0.454 & \\
\hline & $\%$ employment & 0.317 & \\
\hline & $\begin{array}{l}\text { No. of households within } 1 \mathrm{~km} \\
\text { of Park }\end{array}$ & 0.300 & \\
\hline \multirow{6}{*}{$\begin{array}{l}\text { Illegal entry trails per km } \\
\text { of boundary }\end{array}$} & Road distance to Fort Portal & -0.529 & \multirow{6}{*}{$\begin{array}{l}\text { Adjusted } R^{2}=0.620, F=7.529, \mathrm{P}<0.001 \\
\text { Moran's } I=0.316, \mathrm{P}=0.054\end{array}$} \\
\hline & $\%$ in-migration & -0.403 & \\
\hline & Adult education & 0.628 & \\
\hline & Land owned & -0.364 & \\
\hline & Building wealth & -0.499 & \\
\hline & $\begin{array}{l}\text { Transport/communication devices } \\
\text { (bicycle equivalent units) }\end{array}$ & -0.385 & \\
\hline $\begin{array}{l}\text { No. of livestock seen grazing } \\
\text { in Park per village }\end{array}$ & $\begin{array}{l}\text { Cattle ownership (cattle equivalent } \\
\text { units) }\end{array}$ & 0.718 & $\begin{array}{l}\text { Adjusted } R^{2}=0.494, F=24.425, \mathrm{P}<0.001 \text {; } \\
\text { Moran's } I=0.155, \mathrm{P}=0.284\end{array}$ \\
\hline
\end{tabular}

average number of income-generating activities engaged in by households increased with village population density $(r=0.445, \mathrm{P}=0.026, \mathrm{n}=25)$. Villages with higher mean years of adult education also had more income-generating activities $(r=0.557, \mathrm{P}=0.004, \mathrm{n}=25)$. As village employment rose, the percentage of households selling excess food crops dropped $(r=-0.670, \mathrm{P}<0.001, \mathrm{n}=25)$, and the prevalence of income-generating activities rose $(r=0.416$, $\mathrm{P}=0.038, \mathrm{n}=25$ ), as money earned through employment was presumably invested in small businesses.

Market access The closest major urban centre to Kibale National Park is Fort Portal (population 40,988; Uganda Bureau of Statistics, 2010). Most roads around the Park are dirt roads, some improved with murram. The best murram road runs from Fort Portal to Kamwenge (Fig. 1), with access to research, tourism and carbon sequestration operations. There are two well-paved roads, one connecting Fort Portal to the capital, Kampala, and the other connecting Fort Portal to a southern town, Kasese (population 71,700). Fort Portal is the administrative centre for the district of Kabarole and seat of the Toro Kingdom, acting as a market hub for the region. The road distances from study villages to Fort Portal were $14-77 \mathrm{~km}$. Villages closer to Fort Portal had higher employment $(r=-0.603, \mathrm{P}=0.001, \mathrm{n}=25)$ and more income-generating activities $(r=-0.424, \mathrm{P}=0.035$, $\mathrm{n}=25$ ), presumably because households accessed urban markets. Three other urban centres, Kyenjojo (population 20,100), Kamwenge (population 16,100), and Bigodi (population 11,070), are within $15 \mathrm{~km}$ of the Park but there were no significant correlations with road distance to these centres.

Illegal extraction Within the $128 \mathrm{~km}$ long boundary measurement zone (Fig. 1), $19.5 \mathrm{~km}$ of boundary were sampled. Tree extraction was found adjacent to all 25 villages, with high levels of extraction clustered along the western boundary (Table 2). Seventy-five illegal entry trails were recorded, most along the north-west border, with up to 20 trails per $\mathrm{km}$ observed. Herds of goats $(<20$ animals) and cows (100-200) were observed grazing inside the Park near nine villages, most in the southern half of the Park. Only 24 signs of poaching (pitfall traps and snares) were found, near six villages, most along the north-east boundary. Poachers have been known to travel deep into the Park to hunt (PAWAR, 2009) and therefore poaching signs along the Park boundary may not represent the true magnitude of incursions.

Modelled extraction Tree extraction increased closer to Fort Portal (Table 3) suggesting offtake is not only for local consumption but also to supply the town, as supported by proportionally more households making charcoal, selling firewood and owning wood-lots within $20 \mathrm{~km}$ of Fort Portal 
TABle 4 Influence of distance to Fort Portal on tree extraction and wood-based income activities.

\begin{tabular}{|c|c|c|c|}
\hline \multirow[b]{2}{*}{ Village-scale variable } & \multicolumn{2}{|c|}{$\begin{array}{l}\text { Road distance to } \\
\text { Fort Portal }\end{array}$} & \multirow{2}{*}{$\begin{array}{l}t \text {-test } \\
\mathrm{P}\end{array}$} \\
\hline & $\leq 20 \mathrm{~km}$ & $>20 \mathrm{~km}$ & \\
\hline $\begin{array}{l}\text { Mean no. of illegally harvested } \\
\text { trees per km of boundary }\end{array}$ & 261 & 134 & 0.087 \\
\hline $\begin{array}{l}\text { Mean\% of households making } \\
\text { charcoal }\end{array}$ & 12.6 & 2.9 & 0.035 \\
\hline $\begin{array}{l}\text { Mean\% of households selling } \\
\text { firewood }\end{array}$ & 8.4 & 1.7 & 0.015 \\
\hline $\begin{array}{l}\text { Mean\% of households owning } \\
\text { wood-lot }\end{array}$ & 29.4 & 15.2 & 0.057 \\
\hline
\end{tabular}

(Table 4). The number of households within $1 \mathrm{~km}$ of the Park predicts a more localized demand for wood (Table 3 ). The influence of wealth variables on tree harvesting was contradictory, as higher transport/communication device ownership predicted lower illegal tree harvesting $\left(\beta_{\text {standardized }}=-0.454\right)$ but employment predicted increased illegal tree offtake $\left(\beta_{\text {standardized }}=0.317\right)$. Illegal entry trails were predicted by road distance from Fort Portal (Table 3), reinforcing the observation that illegal offtake is augmented by urban demand. Higher adult education also predicted higher numbers of illegal entry trails (Table 3 ) but inmigration predicted fewer illegal entry trails. Capital asset wealth variables (land, building worth, and transportation and communication devices) also predicted fewer illegal entry trails. The number of livestock grazing in the Park was modelled by mean village livestock ownership, suggesting grazing in the Park is primarily driven by local demand (Table 3). A statistically significant model for poaching could not be generated as poaching signs were only found near six villages.

\section{Discussion}

Extraction of trees from protected areas has been attributed to subsistence needs (Masozera \& Alavalapati, 2004), with poorer households being more dependent on forest products (Fisher \& Shively, 2005; Mamo et al., 2007). This infers that restricting access to protected areas further impoverishes poorer households, implying conservation organizations should help alleviate poverty near protected areas either as a moral obligation, or to mitigate resource extraction (Adams et al., 2004; Fisher et al., 2008). However, recent studies have found that poorer households near protected areas are no worse off, and may be better off, than their rural counterparts farther from protected areas (de Sherbinin, 2008; Naughton-Treves et al., 2011) countering the argument that creation of protected areas further impoverishes the poor. In fact, wealthier households, although less dependent on forest products (Lepetu et al., 2009), want more access to forests (Holmes, 2003) and extract larger quantities of charcoal and timber (Mamo et al., 2007). Although conservation organizations can help to reduce poverty locally (Redford et al., 2008), poverty is only one of many factors influencing tropical deforestation (Geist \& Lambin, 2002). Our findings suggest that households within $1 \mathrm{~km}$ of Kibale National Park represent local offtake, either for home consumption or for sale, and that this offtake could be mitigated if households were wealthier. However, our results also highlight that illegal tree harvesting, charcoal making and firewood selling are higher near Fort Portal, repositioning the problem of tree poaching in the protected area from a wildlife agency problem to the much larger issue of regional/national wood demand and deforestation.

In Uganda a projected critical tree shortage has led the government to provide tree seedlings, promote wood-lot planting, initiate an energy-saving stove programme and introduce a tax on tree cutting (Uganda Ministry of Energy, 2009; Uganda Ministry of Water and Environment, 2011). Although given much of the tree harvesting is illegal (de jure), the cutting tax is rarely collected and the energysaving stove programme understandably prioritizes areas with critical tree shortages rather than those near forested protected areas. Other potential policy options would be to tax charcoal production (Namaalwa et al., 2009) or to provide tax credits for creating wood-lots.

Although deforestation is a national issue, wildlife authorities and conservation organizations should better align their goals to integrate into national policy strategies by safeguarding forested protected areas through increased patrols and provision of tree seedlings and energy-saving stoves to neighbouring communities. Although Park boundaries remain intact, the landscape around Kibale National Park has become more fragmented, with forest patches diminishing or disappearing altogether (Hartter \& Southworth, 2009). Fort Portal's population grew by $53 \%$ from 1980 to 2002 (Uganda Bureau of Statistics, 2010). As the town continues to grow, more of the Park boundary could be under pressure from tree poaching. Longitudinal analysis of satellite images to identify the spatial growth rate of urban wood demand could help target areas and timescales at risk of high tree harvesting.

Tree nurseries have been started near Kibale National Park to provide free tree seedlings to local communities and Kabarole District Council has issued an ordinance supplement stating 'all land owners shall plant trees on at least $10 \%$ of the acreage of his or her land as advised by Council' (Kabarole District, 2006, p. 10), suggesting the council would be amenable to finding solutions to reduce harvesting in the Park. However, the wood commodity chain needs to be understood better, as many farmers we spoke to referred to their wood-lots as bank accounts to be 
cashed to pay for large expenses (e.g. sickness, school fees, land). If people grow wood-lots for a one-time sale and sell to an urban centre where prices are higher, this will do nothing to reduce local use and illegal tree harvesting. In this case, NGOs and the Uganda Wildlife Authority may need to help set up community-based wood-lots, which have been found to meet local wood demand effectively in other African countries (De Miranda et al., 2010).

We found that increased capital asset wealth, excluding livestock ownership, was a mitigating factor for tree extraction and illegal entry trails but illegal grazing in the Park rose with higher livestock wealth. Increased wealth may improve attitudes towards protected areas (Infield, 1988; Gillingham \& Lee, 1999) but these attitudes only translate into less illegal extraction if the source of wealth accumulation is not based on protected area resources, a finding consistent with a study in Tanzania (Gillingham \& Lee, 1999). Although grazing in the Park is illegal, research is needed to understand its impact on conservation objectives, especially in times of drought when livestock owners are most in need of grazing pastures (Neumann, 1998). A study in Kibale National Park identified forest encroachment on grasslands in the Park to be adversely affecting small antelope populations (Lwanga, 2006), and therefore controlled grazing of livestock in the Park through negotiated access could help maintain these grasslands.

Whether economic opportunities near protected areas contribute to anthropogenic pressure on them is controversial (De Sherbinin \& Freudenberger, 1998; Wittemyer et al., 2008; Joppa et al., 2009). We found population density was higher near park-based employment. Tree planting requires low labour skills, so carbon sequestration operations may be attracting people, as evidenced by higher inmigration close to FACE plantations. However, tourism and research jobs often require more education, so we believe the higher population density near these employment opportunities represents a localized concentration of skilled labour rather than in-migration from distant areas of Uganda. The in-migration rate in villages near research and tourism sites was at or below the mean value in this study but the mean years of education for men was relatively high (5.4-7.5 years). Illegal tree harvesting was higher near park-based employment opportunities, probably because of higher population density, but also because park-based employment provides increased access to the interior of the Park. Wildlife authorities, local governments and NGOs need to consider the potential migratory pull and increased Park access related to employment by park-based enterprises and plan to provide sources of fuelwood, such as community wood-lots, adjacent to these operations.

Human pressure on forest protected areas can only be managed by identifying local and regional drivers of resource extraction and addressing, in partnership with local authorities, the need for resources. We have demonstrated that demand for park-based resources, from both urban and rural communities, and the proximity of households to the Park drives extraction of forest resources from Kibale National Park. The most extracted resource was wood, a rapidly diminishing resource throughout the country. Conservation organizations therefore need to coordinate their strategies with the broader national policy situation to develop approaches supporting community agroforestry and sustainable development to protect habitat for biodiversity conservation.

\section{Acknowledgements}

Funding for CM was provided by the Warren Development Geography Fund, and McGill Faculty of Science African Field Work Award. JH was funded by the National Science Foundation (CNH-EX 1114977) and National Geographic Research and Exploration grants. The Uganda National Council for Science and Technology, Uganda Wildlife Authority, Makerere University Biological Field Station, and many local officials provided useful assistance and granted permission for this research. We thank our field assistants, all villagers who participated in this study, Dr Breau, Dr Chapman, Dr Sengupta, and anonymous reviewers for insightful comments.

\section{References}

Adams, W.M., Aveling, R., Brockington, D., Dickson, B., Elliot, J., Hutton, J. et al. (2004) Biodiversity conservation and the eradication of poverty. Science, 306, 1146-1149.

Ahrends, A., Burgess, N.D., Milledge, S.A., Bulling, M.T., Fisher, B., SMArT, J.C. et al. (2010) Predictable waves of sequential forest degradation and biodiversity loss spreading from an African city. Proceedings of the National Academy of Sciences of the USA, 107, 14556-14561.

Brook, B.W. \& Bradshaw, C.J. (2006) Momentum drives the crash: mass extinction in the tropics. Biotropica, 38, 302-305.

Bruner, A.G., Gullison, R.E., Rice, R.E. \& da Fonseca, G.A. (2001) Effectiveness of parks in protecting biodiversity. Science, 291, 125-128.

Burgess, N.D., Balmford, A., Cordeiro, N.J., Fjeldsa, J., Kuper, W., RAhвек, C. et al. (2007) Correlations among species distributions, human density and human infrastructure across high biodiversity tropical mountains of Africa. Biological Conservation, 134, 164-177.

Chapman, C.A. \& Lambert, J.E. (2000) Habitat alteration and the conservation of African primates: case study of Kibale National Park, Uganda. American Journal of Primatology, 50, 169-185.

Chapman, C.A., Lawes, M.J. \& Eeley, H.A. (2006) What hope for African primate diversity? African Journal of Ecology, 44, 116-133.

Chapman, L.J., Schneider, K.R., Apodaca, C. \& Chapman, C.A. (2004) Respiratory ecology of macroinvertebrates in a swamp-river system of East Africa. Biotropica, 36, 572-585.

Cropper, M. \& Griffiths, C. (1994) The interaction of population growth and environmental quality. American Economic Review, $84,250-254$. 
De Miranda, R.C., Sepp, S., Ceccon, E., Mann, S. \& Singh, B. (2010) Sustainable Production of Commercial Woodfuel: Lessons and Guidance from Two Strategies. Energy Sector Management Assistance Program Report. World Bank, Washington, DC, USA.

De Sherbinin, A. (2008) Is poverty more acute near parks? An assessment of infant mortality rates around protected areas in developing countries. Oryx, 42, 26-35.

De Sherbinin, A. \& Freudenberger, M. (1998) Migration to protected areas and buffer zones: can we stem the tide? Parks, $8,38-53$.

Dovie, D.B., Witkowski, E.T. \& Shackleton, C.M. (2004) The fuelwood crisis in southern Africa-relating fuelwood use to livelihoods in a rural village. GeoJournal, 60, 123-133.

Ellis, F. \& BAhigGWa, G. (2003) Livelihoods and rural poverty reduction in Uganda. World Development, 31, 997-1013.

Fisher, M. \& Shively, G. (2005) Can income programs reduce tropical forest pressure? Income shocks and forest use in Malawi. World Development, 33, 1115-1128.

Fisher, R., Maginnis, S., Jackson, W., Barrow, E. \& Jeanrenaud, S. (2008) Linking Conservation and Poverty Reduction: Landscapes, People and Power. Earthscan, London, UK.

Geist, H.J. \& Lambin, E.F. (2002) Proximate causes and underlying driving forces of tropical deforestation. BioScience, 52, 143-150.

Gillingham, S. \& Lee, P.C. (1999) The impact of wildlife-related benefits on the conservation attitudes of local people around the Selous Game Reserve, Tanzania. Environmental Conservation, $26,218-228$.

Hartter, J. (2009) Attitudes of rural communities towards wetlands and forest fragments around Kibale National Park, Uganda. Human Dimensions of Wildlife, 14, 433-447.

Hartter, J. (2010) Resource use and ecosystem services in a forest park landscape. Society and Natural Resources, 23, 207-233.

HartTer, J. \& Goldman, A. (2011) Local responses to a forest park in western Uganda: alternative narratives on fortress conservation. Oryx, 45, 60-68.

Hartter, J. \& Southworth, J. (2009) Dwindling resources and fragmentation of landscapes around parks: wetlands and forest patches around Kibale National Park, Uganda. Landscape Ecology, $24,643-656$.

Holmes, C.M. (2003) Assessing the perceived utility of wood resources in a protected area of Western Tanzania. Biological Conservation, 111, 179-189.

INFIELD, M. (1988) Attitudes of a rural community towards conservation and a local conservation area in Natal, South Africa. Biological Conservation, 45, 21-46.

Infield, M., NaAmara, A. \& Marquardt, M. (1993) The Socio-economy, Natural Resource Use, and Attitudes Towards the Park of Communities Living in and around Lake Mburo National Park: Report of a Rapid Rural Appraisal. Makerere Institute of Social Research and the Land Tenure Centre, Kampala, Uganda.

Joppa, L.N., LoArie, S.R. \& Pimm, S.L. (2009) On population growth near protected areas. PLoS ONE, 4(1), e4279.

Kabarole District (2006) Kabarole District (Production and Environment Management) Ordinance Supplement No.1. Uganda Printing and Publishing Corporation, Entebbe, Uganda.

Kideghesho, J.R., Roskaft, E. \& Kaltenborn, B.P. (2007) Factors influencing conservation attitudes of local people in Western Serengeti, Tanzania. Biodiversity and Conservation, 16, 2213-2230.

Kremen, C., Niles, J.O., Dalton, M.G., Daily, G.C., Ehrlich, P.R., FAY, J.P. et al. (2000) Economic incentives for rain forest conservation across scales. Science, 288, 1828-1832.
Leitner, M. \& Curtis, A. (2004) Cartographic guidelines for geographically masking the locations of confidential point data. Cartographic Perspectives, 49, 8-25.

Lepetu, J., Alavalapati, J. \& Nair, P.K. (2009) Forest dependency and its implications for protected areas management: a case study from Kasane Forest Reserve, Botswana. International Journal of Environmental Resources, 3, 525-536.

Lepp, A. \& Holland, S. (2006) A comparison of attitudes towards state-led conservation and community-based conservation in the village of Bigodi, Uganda. Society and Natural Resources, 19, 609-623.

LWAnGA, J.S. (2006) The influence of forest variation and possible effects of poaching on duiker abundance at Ngogo, Kibale National Park, Uganda. African Journal of Ecology, 44, 209-218.

Mamo, G., SjaAstad, E. \& Vedeld, P. (2007) Economic dependence on forest resources: a case from Dendi District, Ethiopia. Forest Policy and Economics, 9, 916-927.

Masozera, M.K. \& Alavalapati, J.R. (2004) Forest dependency and its implications for protected areas management: a case study from the Nyungwe Forest Reserve, Rwanda. Scandinavian Journal of Forest Research, 19, 85-92.

Mbile, P., Vabi, M., Мевoka, M., Okon, D., Arrey-Mbo, J., Nкоngho, F. \& Евоn, E. (2005) Linking management and livelihood in environmental conservation: case of the Korup National Park, Cameroon. Journal of Environmental Management, $76,1-13$.

McDonald, R.I., Forman, R.T., Kareiva, P., Neugarten, R., SAlZER, D. \& Fisher, J. (2009) Urban effects, distance, and protected areas in an urbanizing world. Landscape and Urban Planning, 93, 63-75.

Mwamfupe, D. (1998) Demographic impacts on protected areas in Tanzania and options for action. Parks, 8, 3-14.

Namaalwa, J., Hofstad, O. \& Sankhayan, P.L. (2009) Achieving sustainable charcoal supply from woodlands to urban consumers in Kampala, Uganda. International Forestry Review, 11, 64-78.

Naughton-Treves, L., Alix-Garcia, J. \& Chapman, C.A. (2011) Lessons about parks and poverty from a decade of forest loss and economic growth around Kibale National Park, Uganda. Proceedings of the National Academy of Sciences of the USA, 108, 13919-13924.

Naughton-Treves, L., Kammen, D.M. \& Chapman, C. (2007) Burning biodiversity: woody biomass used by commercial and subsistence groups in western Uganda's forests. Biological Conservation, 134, 232-241.

Neumann, R.P. (1998) Imposing Wilderness: Struggles over Livelihood and Nature Preservation in Africa. University of California Press, Berkeley and Los Angeles, USA.

Newmark, W.D. \& Hough, J.L. (2000) Conserving African wildlife: integrated conservation and development projects and beyond. BioScience, 50, 585-592.

Olupot, W. \& Chapman, C.A. (2006) Human encroachment and vegetation change in isolated forest reserves: the case of Bwindi Impenetrable National Park, Uganda. In Emerging Threats to Tropical Forests (eds W.F. Laurance \& C.A. Peres), pp. 127-142. The University of Chicago Press, Chicago, USA.

Omeja, P.A., Chapman, C.A. \& OвuA, J. (2009) Enrichment planting does not improve tree restoration when compared with natural regeneration in a former pine plantation in Kibale National Park, Uganda. African Journal of Ecology, 47, 650-657.

PAWAR (2009) PAWAR Study Areas-Kibale. Woods Hole Research Center: Protecting the Integrity of the Global Environment. Http:// atlas.whrc.org/pawar/default.aspx?Park=Kibale [accessed 12 May 2010]. 
Plumptre, A.J., Cox, D. \& Mugume, S. (2003) The Status of Chimpanzees in Uganda. Wildlife Conservation Society, New York, USA.

Redford, K.H., Levy, M.A., Sanderson, E.W. \& de Sherbinin, A. (2008) What is the role for conservation organizations in poverty alleviation in the world's wild places? Oryx, 42, 516-528.

Robins, P., McSweeney, K., Waite, T. \& Rice, J. (2006) Even conservation rules are made to be broken: implications for biodiversity. Environmental Management, 37, 162-169.

Rondinini, C., Chiozza, F. \& Boitani, L. (2006) High human density in the irreplaceable sites for African vertebrate conservation. Biological Conservation, 133, 358-363.

Solomon, J., Jacobson, S.K., Wald, K.D. \& Gavin, M. (2007) Estimating illegal resource use at a Ugandan park with the randomized response technique. Human Dimensions of Wildlife, $12,75-88$.

St John, F.A., Edwards-Jones, G., Gibbons, J.M. \& Jones, J.P. (2010) Testing novel methods for assessing rule breaking in conservation. Biological Conservation, 143, 1025-1030.

Sunderlin, W.D., Angelsen, A., Belcher, B., Burgers, P., Nasi, R., Santoso, L. \& Wunder, S. (2005) Livelihoods, forests, and conservation in developing countries: an overview. World Development, 33, 1383-1402.

Takasaki, Y., Barnham, B.L. \& Coomes, O.T. (2000) Rapid rural appraisal in humid tropical forests: an asset possession-based approach and validation methods for wealth assessment among forest peasant households. World Development, 28, 1961-1977.

Tole, L. (1998) Sources of deforestation in tropical developing countries. Environmental Management, 22, 19-33.

Uganda Bureau of Statistics (2009) Population. Http://www. ubos.org/index.php?st=pagerelations $2 \& \mathrm{id}=17 \& \mathrm{p}=$ related $\% 20$ pages \%202:Population [accessed 16 June 2011].
Uganda Bureau of Statistics (2010) Uganda: Regions, Major Cities and Towns-Statistics and Maps on City Population. Http:// www.citypopulation.de/Uganda.html [accessed 20 February 2011].

Uganda Ministry of Energy and Mineral Development (2009) Annual Report 2008, MEMD-2009-001. Kampala, Uganda.

Uganda Ministry of Water and Environment (2011) Water and Environmental Sector Performance Report 2011. Kampala, Uganda.

Uganda Wildlife Authority (2009) Visitor Statistics. Uganda Wildlife Authority Internal Report, Kampala, Uganda.

Uganda Wildife Statute (1996) FAOLEX: Food and Agriculture Organization of the United Nations Legal Office. Http://faolex.fao. org/docs/texts/ugagooo.doc [accessed 25 March 2008].

Wittemyer, G., Elsen, P., Bean, W.T., Coleman, A., Burton, O. \& Brashares, J.S. (2008) Accelerated human population growth at protected area edges. Science, 321, 123-126.

\section{Biographical sketches}

Catrina Mackenzie studies the spatial distribution and effectiveness of benefits and losses accrued as a result of protected areas that influence conservation attitudes and behaviours of local residents. Her research is focused on the socio-economic context of protected areas, and considers influences from local, regional and global economies, with an emphasis on revenue sharing and loss compensation. JOEL HARTTER focuses on social and ecological impacts of landscape change. He has worked on land use and land cover change in and around Kibale National Park and on the impacts of, and responses to, the Park by surrounding communities. He currently leads a project examining population growth and climate and land cover change around parks in the Albertine Rift. 